\title{
ПАМ'ЯТНІ ДАТИ
}

\author{
І.А. Владимирова, І.Б. Філіппов
}

\section{Внесок академіка М.Ф. Шуби в розуміння механізмів синаптичної передачі в гладеньких м'язах}

30 жовтня 2013 р. виповнилося 685 -років 3 дня народження всесвітньо відомого українського вченого, академіка НАН України, завідувача відділу нервово-м'язової фізіології Інституту фізіології ім. О.О. Богомольця НАН України, двічі лауреата Державної премії України Михайла Федоровича Шуби. Вся наукова діяльність М.Ф. Шуби була присвячена дослідженню механізмів функціонування гладеньких м'язів на клітинному та молекулярному рівнях - напрямку, який зародився в середині 50-х років минулого сторіччя $\mathrm{i}$ завдячує своєму становленню і сучасному рівню розвитку таким корифеям фізіологічної науки, як Едіт Бюлбрінг, Тадао Томіта, Хіроші Куріяма, Джефрі Бернсток, Молі Холман, Чен Као, Ендрю Сомліо, Рік Кастілз та інші. Поряд 3 цими іменами по-праву стоїть імя Михайла Шуби.

\section{Як усе розпочиналось}

Свої дослідження в галузі фізіології гладеньких м'язів М.Ф. Шуба розпочав зразу після захисту кандидатської дисертації у 1958 р. працюючи у відділі електрофізіології Інституту фізіології ім. О.О. Богомольця АН УРСР (тепер НАН України) під керівництвом видатного електрофізіолога, вченого і прекрасної людини, Данила Семеновича Воронцова. Досвід і далекоглядність сивочолого академіка помножені на вміння, працелюбність і ентузіазм молодого кандидата наук дали змогу фактично 3 нуля підняти новий напрямок досліджень в Інституті - фізіологію гладень(c) І.А. Владимирова, І.Б. Філіппов ких м'язів. Завдяки зусиллям М.Ф. Шуби і його невеликої групи ці дослідження просувалися настільки успішно, що постало питання про створення в Інституті фізіології ім. О.О. Богомольця спеціалізованого відділу, роботи якого цілком були б зосереджені на 3'ясуванні механізмів збудження-скорочення гладеньких м'язів і нервово-м'язової передачі. У 1969 р. такий відділ під керівництвом уже на той час молодого доктора наук М.Ф. Шуби було створено. Цей відділ став унікальним осередком 3 вивчення гладеньких м'язів на теренах колишнього СРСР, а дослідження, які в ньому проводилися, досягли такого рівня, що почали визначати напрямок розвитоку цього розділу фізіології у світі.

У своїх ранніх працях (1958-1961) М.Ф. Шуба вперше описав явище “фізичного електротону” в гладеньких м'язах і на цій основі запропонував теорію кабельної будови гладеньких м'язів. Це відкриття дало змогу розробити принципово нову концепцію розповсюдження електричних сигналів у гладком'язовій тканині як у свого роду “електричному синцітію”, в якому окремі гладком'язві клітини (ГМК) з'єднані між собою за допомогою електропровідних низькоомних контактів [7]. Такий принциповий прорив у розумінні електрозбудливості гладком'язової тканини став можливим завдяки використанню передових методичних підходів електрофізіологічного дослідження, зокрема, метода сахарозного містка, який у відділі постійно удосконалювався для отри- 
мання все більш якісних відведень електричних сигналів [1].

Апамін - ключ для розуміння медіаторної природи нервової регуляції гладеньких м'язів

Знання про механізми нервового контролю скороченння гладеньких м'язів є надзвичайно важливими для розуміння регуляції рухової активності гладеньких м'язів внутрішніх органів. Тому не випадково, що Михайло Федорович приділяв велике значення вивченню нервово-м'язової передачі в гладеньких м'язах.

Поодиноке електричне подразнея нервових утворень, що знаходяться у товщі гладеньких м'язів стінки шлунково-кишкового тракту (ШКТ), завжди супроводжується виникненням збуджувальних, або гальмівних синаптичних потенціалів (ЗСП або ГСП). Відомо, що збуджувальні синаптичні потенціали вісцеральних м'язів холінергічної природи, в той час як гальмівні - нехолінергічної та неадренергічної природи. Синаптичні потенціали, які генеруються в присутності холіно- і адреноблокаторів, і медіаторна природа яких залишалася довгий час невизначеною, отримали назву неадренергічних і нехолінергічних (НАНХ). I тілки у 1978 р., через 15 років після відкриття НАНХ гальмування, нам уперше вдалося ефективно і зворотно заблокувати ГСП в гладеньких м'язах шлунково-кишкового тракту за допомогою апаміна - поліпептида із бджолиної отрути [3]. Подальші дослідження показали, що апамін вибірково блокує синаптичну передачу та гіперполяризувальну дію екзогенної АТФ і норадреналіну в інтестінальних гладеньких м'язах (рис. 1) [2, 3, 4, 28, 29]. За ініціативою тодішнього директора нашого Інституту, вельми освіченого і далекоглядного вченого, академіка П.Г.Костюка нами використався апамін, який був синтезований і наданий Інституту докт. хім. наук А.I. Мірошниковим 3 Інституту біоорганичної хімії АН СРСР (Москва), що свідчить про плідне наукове співробітництво двох Інститутів колишнього Союзу.
Завдяки апаміну було виявлено не тільки блокування синаптичної та АТФ-викликаної гіперполяризації мембрани ГМК, а і вперше показано існування нехолінергічних ЗСП та деполяризуючої дії АТФ.

У зв'язку з тим, що апамін переважно блокував тільки першу, швидку фазу ГСП гладеньких м'язів усіх відділів кишечника (див. рис. 1,a), можна було припустити, що перша фаза ГСП зумовлена безпосередньою дією АТФ як нейропередатчика, вивільненого 3 нервових закінчень, тоді як друга - дією аденозина, що виникає в результаті розщеплення АТФ. Хоч припущення про роль аденозину згодом не підтвердилось, але воно дало поштовх нашим подальшим пошукам.

Слід зазначити, що дослідження медіаторної та іонної природи двох компонентів ГСП у гладеньких м'язах ШКТ були нами проведені у співробітництві з проф. Джефрі Бернстоком в Університетському коледжі Лондона. Дж. Бернсток $є$ прикладом унікального вченого, який не тільки вперше відкрив ефективне НАНХ-гальмування інтестинальних гладеньких м'язів і висунув теорію його пуринергічної природи [21], а і фактично став засновником сучасної концепції пурінергічної сигналізації. Він запропонував класифікацію пуринорецепторів, об'єднавши рецептори АТФ в так званий Р2-тип, який у свою чергу розпадається на два підтипи - P2X, що являють собою АТФ-керований іонний канал, та Р2Y, які впливають на свої ефектори через G-білки $[17,22]$.

Саме завдяки нашому співробітництву 3 Дж. Бернстоком було показано, що друга фаза синаптичного гальмування не пов'язана 3 активацією аденозинових пуринорецепторів P1-типу на постсинаптичній мембрані ГМК, а має іншу медіаторну природу [25].

Детальне дослідження впливу інтрамуральних нервових волокон різних відділів ШКТ тварин і людини дали змогу виявити як загальні властивості, так і деякі видові особливості цієї синаптичної передачі. Михайло Федорович особливу увагу звертав на 
дослідження медіаторних й іонних механізмів синаптичних потенціалів в ГМК. Для цього було застосовано фармакологічний підход, використовуючи комбінації різних блокаторів іонних каналів і рецепторів. Так, блокатор АТФ-рецепторів, сурамін, пригнічував швидкий компонент ГСП, не впливаючи на повільний [31]. Разом $з$ даними з блокування швидкого компонента ГСП (як і АТФ-викликаної гіперполяризації) апаміном (рис. 2) це загалом підтверджувало його пуринергічну природу. Водночас чутливість другого компонента ГСП до тетраетиламонію та блокатора синтезу оксида азоту (NO) NO-синтаз - LNAME давала підстави вважати, що він має NO-ергічну природу $[33,35]$.

Дослідження фармакологічних дій апаміну показали, що він є ефективним і селективним блокатором кальційзалежних калієвих каналів малої провідності [18]. Цей факт дав нам можливість зробити висновок, що в генерацію першого, швидкого АТФ-залежного компонента ГСП залучені кальційзалежні калієві канали малої провідності. Щодо другого, повільного, NO-ергічного компонента ГСП, то ще у наших спільних експериментах 3 Дж. Бернстоком було показано, що цей, апаміннечутливий компонент ГСП може бути пригнічений малими концентраціями класичного калієвого блокатора тетраетіламонію (ТЕА, 2-5 ммоль/л), що свідчить про участь у його генерації інших калієвих кналів - найімовірніше кальційзалежних калієвих каналів великої провідності [4]. Пряму підтримку наявності двох типів кальційзалежних калієвих каналів (малої та великої провідності) у мембрані ГМК було отримано i в експериментах на ізольованих клітинах із застосуванням методу фіксації потенціалу [27]. Слід зазначити, що відсутність нехолінергічних ЗСП у ГМК дистального відділу товстої кишки морської свинки за наявності апаміну навряд чи можна було пояснити великими калієвими струмами тому, що за звичайних умов ці м'язи генерують спонтанні потенціали дії.

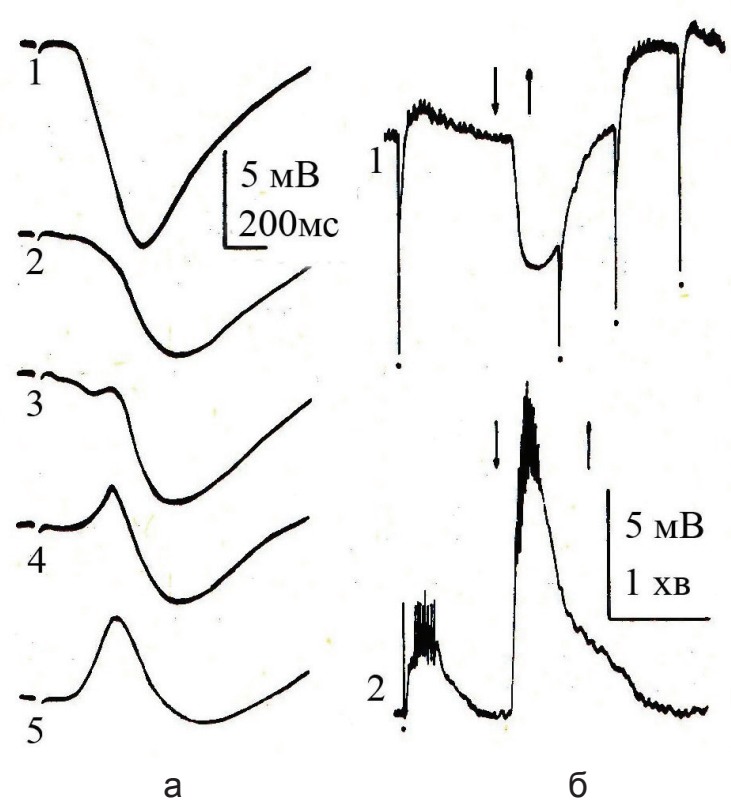

Рис. 1. Апамін-викликане пригнічення неадренергічного гальмування (а) та АТФ-викликаної гіперполяризаціїі (б) гладком'язових клітин taenia coli морської свинки. На а: 1 - гальмівні синаптичні потенціали гладком'язових клітин (ГСП ГМК) та АТФ-викликана гіперполяризація до дії апаміну, 2, 3, 4, 5 - після 1-, 2-, 3-, 5-ї хвилини дії апаміну (0,5 мкмоль/л) відповідно; на б: 2 - АТФ-викликана деполяризація після 20 хв дії апаміну. Стрілки вниз - момент додавання речовин у розчин Кребса, вверх - початок відмивання препарату нормальним розчином Кребса [29] 


\section{Внутрішньоклітинні сигнальні механізми регуляції гладеньких м'язів}

Одним $з$ перспективних напрямків роботи відділу, розробку якого Михайло Федорович доручив співробітнику відділу канд. біол. наук Філіппову І.Б., було дослідження залучення внутрішньоклітинних шляхів у процеси генерації синаптичних потенціалів та дію нейропередатчиків. У зв'язку з тим, що гальмівна дія АТФ на гладенькі мязи кишечника здійснюється через метаботропні Р2Y-рецептори, які спряжені з фосфоліпазою C (PLC) [26] $з$ наступною мобілізацією кальцію, для встановлення ii ролі і пов'язаних 3 нею внутрішньоклітинних сигнальних посередників у механізмах генерації ГСП, використовували фармакологічне пригнічення функції PLC за допомогою U73122. Було показано (рис. 3), що U73122 зменшує амплітуду гальмівних синаптичних потенціалів ГМК незалежно від відділу кишечника. Водночас U73122 майже не змінював амплітуду нехолінергічних ЗСП i NO-ергічного компонента ГСП, вказуючи на те що функціонування PLC необхідне саме для генерації пуринергічного компонента гальмівних синаптичних потенціалів [15].

Таким чином, було виявлено два можливих сигнальних механізми генерації ГСП та АТФ-індукованої гіперполяризації через P2Y-пуринорецептори: перший, через сти-

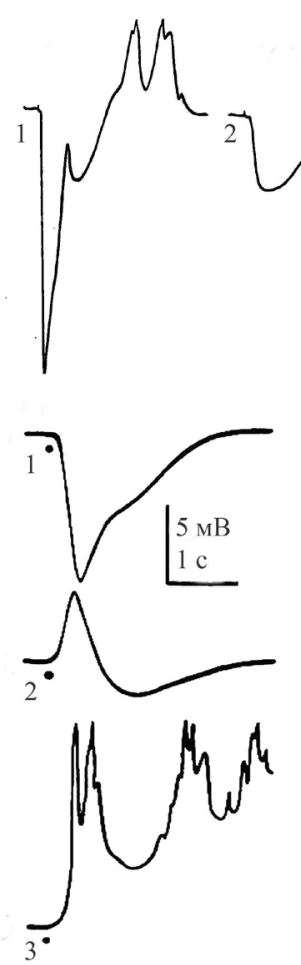

б

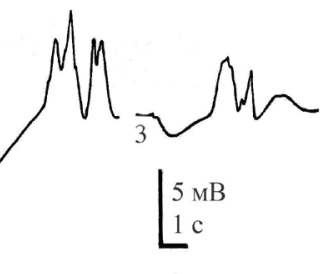

a

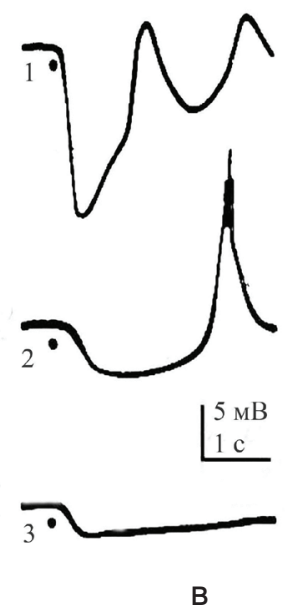

Рис. 2. Комплексна медіаторна та іонна природа гальмівних синаптичних потенціалів гладком'язових клітин шлунково-кишкового тракту. На а: 1 - двокомпонентний гальмівний синаптичний потенціал (ГСП), який виникає у відповідь на поодиноке інтрамуральне електричне подразнення гладеньких м'язів дистального відділу товстої кишки морської свинки, 2 - апамінечутливий компонент ГСП, що відводиться після блокування першого АТФ-залежного компонента апаміном $\left(5 \times 10^{-7}\right.$ моль/л, 15 хв), 3 - синаптична відповідь при сумісній дії апаміну та блокатора NO-cинтази L-NAME $\left(10^{-4}\right.$ моль/л, 12 хв) [33]. На б-в: 1 - гальмівні синаптичні потенціали гладком'язових клітин (ГСП ГМК) сліпої та товстої кишки морської свинки, 2 - апамінвикликане $\left(5 \times 10^{-7}\right.$ моль/л, 20 хв) блокування ГСП ГМК обох відділів кишечника, 3 апамін разом з блокатором калієвої провідності тетраетиламонієм (ТЕА, 2 ммоль/л, 10 хв). Нехолінергічні збуджувальні синаптичні потенціали (ЗСП) в ГМК сліпої кишки $(6,3)$ досягли порога генерації потенціалів дії, а ЗСП в гладеньких м’язах дистального відділу товстої кишки (в, 3) при сумісній дії апаміну і ТЕА не виявлені [30] 
муляцію PLC, вивільнення $\mathrm{Ca}^{2+} 3$ інозитолтрифосфат( $\left.\mathrm{IP}_{3}\right)$-чутливого внутрішньоклітинного кальцієвого депо та активації апамінчутливих кальційзалежних калієвих каналів малої провідності, а другий - $з$ залученням $\mathrm{NO}$ та вивільненням $\mathrm{Ca}^{2+} 3$ ріанодинчутливого внутрішньоклітинного кальцієвого депо, що призводить до активації кальційзалежних калієвих каналів великої провідності [30].

Багатогранність таланту Михайла Федоровича в організації наукових досліджень проявлялась у тому, що при виявленні якогось явища ним зразу ставилися завдання його подальшого поглибленого дослідження на різних рівнях 3 використанням найрізноманітніших методичних підходів. Так, якщо була, наприклад, показана участь вторинних посередників у пуринергічному гальмуванні, то його одразу цікавило, а які ж механізми такого залучення? При цьому підключався весь методичний арсенал: від тензометрії на багатоклітинних препаратах, до електрофізіології й кальційметрії на ізольованих клітинах з залученням широкого спектра фармакологічних засобів. Цей підхід дав змогу показати, що за умов преактивації мускаринових М-холінорецепторів мембрани ГМК карбахоліном, АТФ-викликане розслаблення вісцеральних гладеньких м'язів перестає залежати від PLC. Однак, незважаючи на набуту PLC-незалежнісь ATФ-викликане розслаблення карбахолінового скорочення продовжувало здійснюватися через активацію $\mathrm{IP}_{3}$-чутливих рецепторів. Про це свідчило повне пригнічення гальмівної дії АТФ на тлі карбахоліндукованого скорочення після

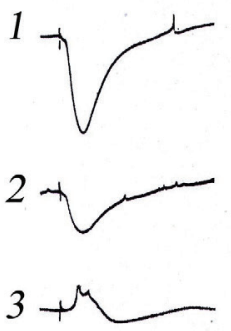

a
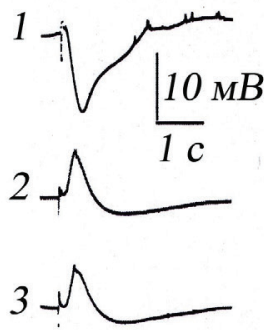

6
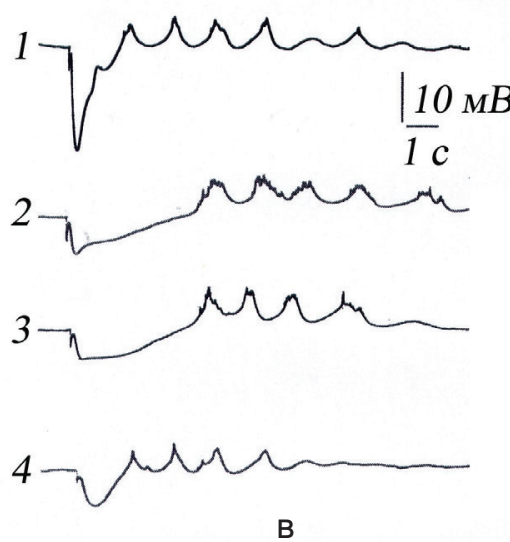

Рис. 3. Дія блокатора фосфоліпази C U73122 на гальмівні та збуджувальні потенціали та NO-ергічний компонент гальмівних синаптичних потенціалів (ГСП) сліпої (а, б) та товстої (в) кишки морської свинки. На а: 1 - контроль, 2 - зменшення ГСП під дією U73122 (10 - збуджувальні синаптичні потенціали (ЗСП) на 30-й хвилині дії апаміну, 3 - резистивний 3СП до дії U73122 (апамін та U73122). На в: 1 - контроль, 2- апамінрезистивний компонент ГСП (апамін, 10-7 моль/л, 30 хв), 3 - апамінрезистивний компонент ГСП не чутливий до дії U73122 (10-5 моль/л, 30 хв), 4 - зменшення тривалості ГСП під впливом L-NNA (10-4 моль/л) за наявності U73122 [30] 
преінкубації гладеньких м'язів у 100 мкмоль блокатора $\mathrm{IP}_{3}$-рецепторів 2-аминоэтоксидифенил борату (2-АРВ).

Селективне блокування або $\mathrm{M}_{2}$, , або $\mathrm{M}_{3}$-холінорецепторів супроводжується повною втратою здатності згаданого блокатора $\mathrm{IP}_{3}$-рецепторів (2-AРВ) пригнічувати АТФ-індуковане розслаблення гладеньких м'язів, що знаходяться в стані карбахоліндукованого скорочення. Можна припустити, що в умовах селективної преактивації $\mathrm{M}_{2}$ - або $\mathrm{M}_{3}$-холінорецепторів механізми внутршньоклітинної сигналізаї, опосередковуючі гальмування, змінюються. За цих умов галмівна дія нейротрансмітерів здійснюється через $\mathrm{IP}_{3}$ незалежний шлях, тобто, шлях що зумовлює i адренергічне, i пуринергічне гальмування гладеньких м'язів виключається.

Таким чином, у проведених дослідженнях уперше було виявлено відмінності між клітинними механізмами гальмування гладеньких м'язів, викликаного дією екзогенної АТФ в умовах селективної активаци або $\mathrm{M}_{2}$, або $\mathrm{M}_{3}$-холінорецепторів, і механізмами розслаблювальної дії гальмівних нейропередавачів за умовах сумісної синергічної активації мускаринових холінорецепторів обох згаданих підтипів [6].

Так, проведені дослідження вперше показали відмінності у механізмах АТФ-індукованого гальмування вісцеральних гладеньких м'язів за умов фізіологічної норми та на тлі збілшеного холінергічного збудження за патологічних умов. Це відкриття свідчить про пластичність механізмів внутрішньоклітинної сигналізації, спряжених 3 тим чи іншим мембранним рецептором, в залежності від того чи цей рецептор активований ізольовано, чи одночасно з іншими типами рецепторів.

Відомо, що контроль функціонування нервових і м'язових клітин через деякі типи поверхневих рецепторів здійснюється також завдяки їх спряженню 3 внутрішньоклітинною аденілатциклазною сигнальною системою. Показано, наприклад, що клоновані P2Y11-пуринорецептори за посередництвом різних $\mathrm{G}$-білків $\left(\mathrm{G}_{\mathrm{q} / 11}\right.$, або $\left.\mathrm{G}_{\mathrm{s}}\right)$ можуть бути двояко сполучені як з PLC, так і з аденілатциклазою (АС), яка синтезує цАМФ [19]. Зважаючи на виявлену нами складну медіаторну природу неадренергічних ГСП, ми припустили, що PLC-незалежний пурінергічний компонент, можливо, зумовлений цАМФ-опосередкованими механізмами. Дослідження, спрямовані на перевірку цього припущення, показали, що активація $\mathrm{AC}$ за допомогою форсколіну не впливає на генерацію ГСП атропінізованих м'язів товстої кишки морської свинки, однак в неатропінізованих гладеньких м'язах форсколін пригнічував ГСП до такого ступеня, що у відповідь на інтрамуральне подразнення вони замість ГСП генерували М-холінергічні ЗСП. Відмінності між дією форсколіну на ГСП в атропінізізованих і неатропінізованих м'язах свідчать про наявність в умовах одночасної активації М-холінорецепторів і Р2Y-пуринорецепторів взаємодії їх внутрішньоклітинних сигнальних шляхів, що виявляється при активації AC [14]. Отже, у пурінергічне гальмування гладеньких м'язів ШКТ виявляються злученими два мембранних фермента - PLC та $\mathrm{AC}$, внаслідок взаємодії яких запускаються множинні внутрішньоклітинні сигнальні шляхи. На міру участі цих ферментів може впливати вихідний функціональний стан інтестинальних гладеньких м'язів. Ці зміни завжди спрямовані на підтримування нормального функціонування органів травного тракту [15].

У 80-ті роки минулого сторіччя Михайлом Федоровичом були ініційовані дослідження, спрямовані на з'ясування особливостей перебігу синаптичних процесів у гладеньких м'язах кишечника людини. Їх результатом цих досліджень було доведення нехолінергічної, неадренергічної природи синаптичного гальмування у кільцевих та повздовжніх м’язах тонкої та товстої кишки людини, отримання доказів на користь медіаторної ролі АТФ у гальмівних процесах, встановлення кальційзалежної калієвої природи гальмівних 
синаптичних потенціалів і виявлення особливостей генерації ГСП при окремих патологічних змінах в кишечнику, зокрема, при хворобі Гиршспрунга [9, 34]. Учні та послідовники Михайла Федоровича, зокрема докт. біол. наук О.В. Романенко та канд. біол. наук М.М. Груша, підтримали естафету клінічно-орієнтованих досліджень і успішно продовжують їх розвивати на кафедрі біології Київського медичного університету [8, 10, 11, 12, 13].

\section{Іонна природа дії нейромедіаторів на гла- денькі м'язи}

Збуджувальний, чи гальмуючий ефект нейромедіаторів залежить від того, які іони беруть участь у змінах мембранної провідності, викликаної дією цих медіаторів на відповідні мембранні рецептори. При цьому особливе значення для регуляції скорочення ГМК має здатність нейромедіатора індукувати вхід чи вивільнення кальцію. У вісцеральних гладеньких м'язах, зокрема у м'язах ШКТ, ацетилхолін є основним збуджувальним нейромедіатором. М.Ф. Шуба почав вивчати дію ацетилхоліну на показники електротону вісцеральних гладеньких м'язів ще у 60-х роках минулого сторіччя. При цьому особливу увагу він приділяв саме питанням іонної природи холінергічного збудження [16]. На сучасному рівні дослідження мебранних провідностей ГМК, пов'язаних з активацією підтипів мускаринових холінорецепторів, розвивав у відділі докт. біол. наук О.В. Жолос. 3 середини 90-х років ці дослідження переросли у предмет тісного наукового співробітництва відділу з лабораторією клінічної фармакології Госпіталю Святого Георгія при Лондонському університеті, очолюваною відомим спеціалістом в галузі фізіології, фармакології і біофізики гладеньких мязів проф. Томасом Болтоном. Необхідно зазначити, що М.Ф. Шуба та Т. Болтон познайомилися ще у 1974 р. під час стажування обох у лабораторії проф. Едіт Бюлбрінг у Оксфордському університеті, i їх тісні наукові контакти зберігалися впродовж усього життя Михайла Фе- доровича. У відповідних дослідженнях були встановлені пряма роль рецепторів $\mathrm{M}_{2}$-типу i дозвільна функція рецепторів $\mathrm{M}_{3}$ типу в активації мускаринових катіонних каналів, а також визначена роль G-білків у передачі сигналу від рецептора та регуляції потенціалзалежності цих каналів [36, 37, 38]. Нещодавно за участю вихованців відділу О.В. Жолоса та В.В. Цвіловського з використанням «нокаутних» тварин була остаточно розшифрована молекулярна природа холінергічного збудження ГМК ШКТ, яка, як виявилося, базується на активації двох типів рецепторкерованих кальційпроникних катіонних каналів родини TRP (від англ. Transient Receptor Potential), a саме TRPC4 і TRPC6 [32]. Дослідженням того, які молекулярні системи входу, вивільнення, захоплення та виведення кальцію в ГМК регулюються тими чи іншими нейромедіаторами займалася у відділі група канд. біол. наук Д.В. Гордієнко. Такого типу дослідження могли ефективно проводитися тільки із застосуванням лазерної конфокальної мікроскопії та флуоресцентних барвників, здатних мітити як іони кальцію, так і субклітинні структури. Оскільки таке складне інструментальне забезпечення в Україні було недоступне, ці роботи також проводилися на колаборативній основі 3 лондонською лабораторією проф. Т. Болтона. Результатом цих робіт став опис подій локального вивільнення $\mathrm{Ca}^{2+}$ з саркоплазматичного (СР) ретикулума ГМК, отримання безпосередніх і деталізованих даних з наявності кальційіндукованого вивільнення кальцію (CICR) з CP різних типів ГМК, аналіз ультраструктури, просторової організації та обчислення об'єму СР свіжоізольованих ГМК [20, 23, 24]. Було зроблено висновок, що просторова організація СР ГМК забезпечує збільшення щільності місць вивільнення $\mathrm{Ca}^{2+}$ у поздовжньому напрямку і таким чином сприяє розповсюдженню кальцієвих хвиль вздовж гладеньком'язової клітини під час скорочення, викликане дією медіаторів. 


\section{Клінічні аспекти досліджень}

М.Ф. Шуба опікувався не тільки розвитком фундаментальних досліджень в галузі фізіології та біофізики гладеньких м'язів, а і намагався використати їх результати для розробок в прикладній медицині. Так, наприклад, із співробітникам кафедри хірургії Київського медінституту були проведені спільні дослідження синаптичної передачі, дії медіаторів та модуляторів синаптичної передачі на ізольованиі смужки гладеньких м'язів шлунка, тонкої і товстої кишки людини (хворих, оперованих 3 приводу виразки шлунка та дванадцятипалої кишки, доброякісних і злоякісних пухлин тощо). Відомо, що оперативне втручання на органах черевної порожнини нерідко супроводжується післяопераційними парезами ШКТ. За наявними нині уявленнями, одна $з$ причин післяопераційних парезів - посилення гальмівного впливу симпатичної нервової системи внаслідок рефлекторної активації адренергічних нейронів. У медичній практиці для усунення цього гальмування використовують перидуральную анестезію, симпатолітики і адреноблокатори, що, однак, не завжди призводить до бажаних результатів. Вважається, що однією з можливих причин недостатньої ефективності такого лікування може бути активація стійких до дії адреноблокаторів пурінергічних нейронів ентерального нервового сплетіння. Відсутність специфічного блокатора пуринергічного гальмування ускладнює встановлення причин післяопераційних парезів і поки не дає змоги їх усувати спрямованим впливом на цей тип гальмування.

Крім виключення адренергічного гальмування, в лікувальній практиці використовується також метод фармакологічної стимуляції моторно-евакуаторної функції ШКТ за допомогою антихолінестеразних засобів (прозерин, убретид). Однак у разі поширеня запального процесу на нервові терміналі, виділення ацетилхоліну припиняється, і вве-

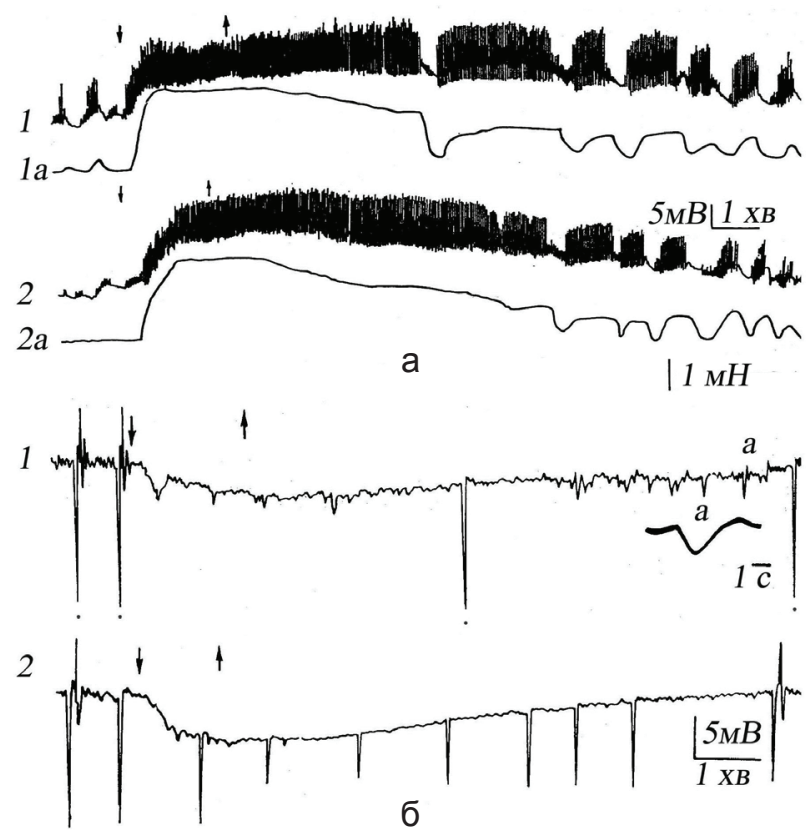

Рис. 4. Збуджувальний (а) і гальмівний (б) ефект серотоніну (10-6 моль/л) на гладенькі м'язи тонкої та товстої кишки людини: а - електрична (1) та скорочувальна (1а) активність м’язової смужки, тонкої кишки, відповідно, б - ідентичність ефектів серотоніну й АТФ (гіперполяризація, виникнення спонтанних і зменшення викликаних гальмівних синаптичних потенціалів (ГСП) на гладком'язові клітини кільцевого шару товстої кишки (1,a - спонтаний ГСП на більшій швидкості розгортки) [5]. Стрілки вниз - момент додавання речовин у розчин Кребса, вверх - початок відмивання препарату нормальним розчином Кребса [29] 
дення прозерину виявляється неефективним.

У регуляції рухової активності ШКТ, крім класичних нейромедіаторів, беруть також участь і інші фізіологічно активні речовини, що вивільнюються нейронами ентерального сплетіння. Особливої уваги заслуговує серотонін оскільки в гангліях міентерального сплетіння наявні серотонінергічні нейрони, що передбачає їх можливе залучення в регуляцію та модуляцію рухової активності. У порівнянні з іншими органами і тканинами організму, гладенькі м’язи травного тракту людини мають найбільш високу чутливість до дії цього аміну. Крім того, серотонін впливає на перистальтичну активність. Для встановлення механізмів дії серотоніну на гладенькі м'язи ШКТ і доцільності його застосування в клініці для лікування післяопераційних парезів Михайлом Федоровичом була ініційована спільна робота з кафедрою хірургії Київського медичного інституту ім. О.О.Богомольця 3 вивчення впливу цього аміну на гладенькі м’язи тонкої й товстої кишки людини.

Проведені у відділі дослідження ефектів серотоніну на гладенькі м'язи різних відділів ШКТ показали, що він викликає найбільшу збуджувальну дію у початковому відділі тонкої кишки (рис. 4). Вона слабкішає в аборальному напрямку і вже в початкових відділах товстої кишки збудливий ефект не проявляється зовсім (див. рис. 4). При цьому одночасне розслаблення гладеньких м'язів товстої кишки, викликане серотоніном, полегшує перистальтичну активність [5].

Проведені клінічні спостереження на більш як сотні хворих, які перенесли оперативне втручання на органах черевини і мали післяопераційні порушення моторно-евакуаторної функції травного тракту, показали, що підшкірне введення серотоніну (10 мг) на 2-гу - 3-тю добу післяопераційного періоду стимулювало перистальтичну активність i знімало здуття живота. Введення серотоніну не викликало побічних явищ 3 боку серцево-судинної та дихальної систем. Отже, проведені з нашою безпосередньою участю клініко-експериментальні дослідження дали можливість рекомендувати серотонін як засіб для лікування післяопераційних парезів кишечника.

\section{Підсумок}

Академік М.Ф. Шуба є засновником школи 3 вивчення гладеньких м'язів в Україні та на теренах колишнього СРСР. В Інституті фізіології ім. О.О. Богомольця НАН України йому вдалося створити унікальний науковий колектив, який, незважаючи на багато обмежень радянської доби і складнощі пострадянського періоду розвитку науки в Україні, здобув міжнародне визнання. Михайло Федорович зробив декілька важливих концептуальних кроків у фізіології гладеньких м'язів таких, як відкриття електричного зв'язку між ГМК та нехолінергічного синаптичного збудження в інтестінальних гладеньких м'язах. М.Ф. Шубою разом зі спіробітниками і учнями було показано ефективне блокування апаміном пуринергічного компонента синаптичної передачі, складну медіаторну та іонну природу неадренергічних синаптичних потенціалів, два можливих механізми генерації пуринергічного та NO-ергічного компонентів ГСП: перший - вивільнення $\mathrm{Ca}^{2+}$ із інозитолтрифосфатчутливого кальцієвого депо й активації апамінчутливих кальційзалежних калієвих каналів малої провідності, і другий вивільнення $\mathrm{Ca}^{2+}$ із ріанодинчутливого кальцієвого депо й активації кальційзалежних калієвих каналів великої провідності, виявлено фосфоліпаза С-залежний та незалежний копоненти синаптичного гальмування, досліджено фармакобіофізичні властовості апамінчутливого компонента кальційзалежного калієвого струму ГМК, іонні механізми та кальцієву сигналізацію холінергічного збудження.

Праці акад. М.Ф. Шуби ще тривалий час будуть надихати молодих учених і досвідчених фахівців у галузі фізіології та біофізики гладеньких м'язів на нові творчі пошуки. Науковий колектив, керований Михайлом Фе- 
доровичом, привернув до фізіології гладеньких м'язів багато талановитої молоді, давши змогу їй отримати відмінні дослідницькі навички та здобути наукові ступені. Дякуючи міжнародній репутації Михайла Федоровича, багатьом $з$ його учнів вдалося продовжити кар'єру за кордоном і стати відомими міжнародними вченими. Таким чином Михайло Федорович Шуба підживлював полум’ я науки та фізіології гладеньких м'язів у самій Україні й одночасно давав йому шлях для виходу на більш широкі міжнародні простори.

\section{СПИСОК ЛІТЕРАТУРИ}

1. Артеменко Д.П., Бурый В.А., Владимирова И.А.Шуба М.Ф. Модификация метода одиночного сахарозного мостика // Фізіол. журн. - 1988. - 28, №3. - Р. 374-380.

2. Байдан Л.В., Владимирова И.А., Мирошников А.И., Таран Г.А. Действие апамина на синаптическую передачу в различных типах синапсов // ДАН СССР. - 1978. - 241, №5. - Р. 1224-1227.

3. Владимирова. И.А,. Шуба М.Ф. Влияние стрихнина, гидрастина и апамина на синаптичсекую передачу в гладкомишечних клетках // Нейрофизиология / Neurophysiology. - 1978. - 10, №3. - Р. 295-299.

4. Владимирова И.А., Шуба М.Ф., Синаптические процессы в гладеньких мышцах // Там же. - 1984. - 16, №3. - Р. 307-319.

5. Владимирова І.А., Вовк Е.В., Черпак Б.Д., Шуба М.Ф. Дія серотоніну на ізольовані гладенькі м'язи шлунково-кишкового тракту людини і можливість його застосування в клініці // Фізіол. журн. - 1986. - 32, №6. - С. 671-680.

6. Владимирова И.А, Филиппов И.Б., Кулиева Е.М., Діскина Ю.Б., Ганиткевич В.Я. Отличия клеточных механизмов АТФ- и норадреналин-индуцированного торможения гладеньких мышц в условиях селективной и совместной активации $\mathrm{M}_{2}$ - или $\mathrm{M}_{3}$-холинорецепторов // Нейрофизиология / Neurophysiology. - 2007. - 39, № 1. - Р.22-31.

7. Воронцов Д.С., Шуба М.Ф. Физический електротон нерва и мишцы / К.: Наук. думка, 1966. - Р. 214

8. Груша М.М., Романенко О.В. Синаптичне гальмування в гладеньких м'язах ободової кишки у людей різних вікових груп // Нейрофизиология / Neurophysiology. - 2012. - 4, № 2. - С. 128-136.

9. Загороднюк В.П., Шуба М.Ф. Природа неадренергичсекого торможения в гладеньких мышцах кишечника // Там же. - 1986. - 18, № 3. - Р. 373-381.

10. Романенко О.В., Груша М.М.,. Фомін П.Д. Блокувальна дія піридоксаль-5'-фосфату на неадренергічне синаптичне гальмування гладеньких м'язів тонкого кишечника людини // Фізіол. журн. - 2006. - 52,
№ 1. - C. $62-70$.

11. Романенко О.В., Груша М.М. Синаптичне гальмування гладеньких м'язів ободової кишки людини та вплив на нього вітаміну $\mathrm{B}_{6}$ і його похідних // Нейрофизиология / Neurophysiology. - 2006. - 38, № 4. - С. 269-279.

12. Романенко О.В., Груша М.М. Вплив піридоксаль5 '-фосфату на синаптичне гальмування гладеньких м'язів кишки людини на фоні дії ізоніазиду // Експерим. та клініч. фізіологія і біохімія. - 2006. - 35, № 3. - C. 98-103.

13. Романенко А.В. Груша М.М. Действие галоперидола, клотримазола и пиридоксаль-5'-фосфата на синаптическую передачу в гладеньких мышцах ободочной кишки человека // Нейрофизиология / Neurophysiology. - 2007. - 9, № 4/5 - С. 408-411.

14. Филиппов И.Б., Владимирова И.А., Ганиткевич В.Я. Шуба М.Ф. Модуляция аденилатциклазой взаимодействия возбуждающих и тормозящих синаптических влияний на гладкие мышцы // Там же. - 2004. - 36, №5/6. - Р. 443-445.

15. Филиппов И.Б., Владимирова И.А., Кулиева Е.М. Шуба М.Ф. Участие вторичных внутриклеточных посредников в механизмах пуринергичного торможения интестинальных гладеньких мышц // Нейрофизиология. - 2010. - 42, №3. - С.192-199.

16. Шуба М.Ф. Дія ацетилхоліну на фізіологічний електротон гладеньких м'язів // Фізіол. журнал. - 1962. - 8. - P. 449-455.

17. Abbrachio M.P and Burnstock G. Purinoceptors: Are there families of P2X and P2Y purinoceptors? // Pharmacol. Ther. - 1994. - 64. - P. 445-475.

18. Banks B.E. Brown C., Burgess G.M. Burnstock G., Claret M., Coocks T.M., Jenkinson D.H. Apamin blocks certain neurotransmitter - induced increase in potassium permeability // Nature. - 1979. - 282, № 5707. - P. 415-417.

19. Boeynaems J.M., Communi D., Savi P., Herbert J.M. P2Y receptors: in the middle of the road. Trends. Pharmacol. Sci. - 2000. - 21. - P.1-3.

20. Bolton T.B., Prestwich S.A., Zholos A.V., Gordienko D.V. Excitation-contraction coupling in gastrointestinal and other smooth muscles // Ann. Rev. Physiol. - 1999. -61. - P. 85-115.

21. Burnstock G., Campbell, G., Satchell D.,Smythe A. Evidence that adenosine triphosphate or a related nucleotide is the transmitter substance releases by nonadrenergic nerves in the gut // Brit. J. Pharmacol. - 1970. -40. - P. 668-688.

22. Fredholm B.B., Abbracchio M.P., Burnstock G., Daly J.W., Harden K.T., Jacobson K.A., Leff P., Willams M. Nomenclatuire and classification of purinoceptors // Pharmacol. Rev. - 1994. - 46. - P. 143-156.

23. Gordienko D.V., Zholos A.V., Shuba M.F., Bolton T.B. Mechanisms of calcium signaling in smooth muscle cells explored with fluorescence confocal imaging // Neurofizuoilogiya/Neurophysiology. - 2004. - 36. - P. 455-465.

24. Gordienko D.V., Harhun M.I., Kustov M.V., Pucovský V., Bolton T.B. Sub-plasmalemmal $\left[\mathrm{Ca}^{2+}\right]_{\mathrm{i}}$ upstroke in 
myocytes of the guinea-pig small intestine evoked by muscarinic stimulation: $\mathrm{IP}_{3} \mathrm{R}$-mediated $\mathrm{Ca}^{2+}$ release induced by voltage-gated $\mathrm{Ca}^{2+}$ entry // Cell Calcium. 2008. - 43. - P. 122-141.

25. Hoyle C.H., Vladimirova I.A., Burnstock G. Pre- and postjunctional actions of purine and xanthine compounds in the guinea-pig caecum circular muscle // Brit. J. Pharmacol. - 1988 - 9, №2. - P. 653-663.

26. Kegelgen I., Wetter A. Molecular pharmacology of P2Y receptors // Naunyn-Schmiedeberg's Arch Pharmacol. 1997. - 7. - P. 310-323.

27. Povstyan A.V., Zima A. V., Harhun M.I. Shuba M.F. Properties of the apamin-sensitive component of $\mathrm{Ca}$ ${ }^{2+}$-dependent $\mathrm{K}^{+}$current in smooth muscle cells of the guinea-pig taenia coli // Neurofizuoilogiya / Neurophysiology. - 2000. - 32, № 1. - P. 63-87.

28. Shuba M.F., Vladimirova I.A. Effect of apamin on the electrical responses of smooth muscle to adenosine 5 'triphosphate and to non-adrenergic, non-cholinergic nerve stimulation // Neuroscience. - 1980. - 5. - P.853-859.

29. Shuba M.F. Vladimirova I.A. Action of apamin on nervemuscle transmission and the effect of ATP and noradrenaline in smooth muscles // $28^{\text {th }}$ International congress of physiological sciences // Budapest. - 1980. - Pergamon press. - P. 111-126.

30. Shuba M. F., Vladimirova I. A., Philyppov I. B. Mechanism of the inhibitory action of neurotransmitters on smooth nuscles // Neurofizuoilogiya / Neurophysioloy // 2003. - 35, № 3/4. - P. 252-261.

31. Shuba M.F., Vladimirova I.A, Ermakova T.O., Jurkiewicz A. Mechanisms of nonadrenergic noncholinergic synaptic transmission in smooth muscle cells of the gastrointestinal

Ін-т фізіології ім. О.О.Богомольия НАН Украӥни, Київ E-mail:irinav@biph.kiev.ua tract // Neurofizuoilogiya / Neurophysiology. - 1998. 30, № 4/5. - P. 208-212.

32. Tsvilovskyy V.V., Zholos A.V., Aberle T. Philipp S.E., Dietrich A., Zhu M.X., Birnbaumer L., Freichel M., Flockerzi V. Deletion of TRPC4 and TRPC6 in mice impairs smooth muscle contraction and intestinal motility in vivo // Gastroenterology. - 2009. - 137. - P. 1415-1424.

33. Vladimirova I.A., Zagorodnyuk V.P, Ostrovsky I.V., Sorokina Z.A,.Chizhmakov I.V, Shuba M.F. Ultrasondinduced changes in synaptic processes with different transmitters in smooth muscle // Neurofizuoilogiya / Neurophysiology. - 1993. - 24, № 4. - P. 251-255.

34. Zagorodnyuk V.H., Vladimirova I.A., Vovk E.V., Shuba M.F. Studies of the inhibitory nonadrenergic neuromuscular transmission in the smooth muscle of the normal human and from a case of Hirchsprung,s disease // J. Auton. Nerv. Syst. - 1989. - 26, № 4. - P. 51-60.

35. Zagorodnyuk V.P, Zima A.V., Vladimirova I.A, Shuba M.F. Nitric oxide as a nonadrenergic inhibitory transmitter in smooth muscle cells of the guinea pig gastrointestinal tract: machanism of action // Neurofizuoilogiya / Neurophysiology. - 1994. - 26, №2. - P. 86-91.

36. ZholosA.V., Bolton T.B. G-protein control of voltage dependence as well as gating of muscarinic metabotropic channels in guineapig ileum // J. Physiol. - 1994. - 478. - P. 195-202.

37. Zholos A.V., Bolton T.B. Muscarinic receptor subtypes controlling the cationic current in guinea-pig ileal smooth muscle // Brit. J. Pharmacol. - 1997. - 122 - - P. 885-893.

38. Zholos A.V., Tsytsyura Y.D., Philyppov I.B., Shuba M.F., Bolton T.B. Voltage-dependent inhibition of the muscarinic cationic current in guinea-pig ileal cells by SK\&F 96365 // Ibid. - 2000. - 129, № 4. - P. 695-702.
Матеріал надійшов до редакиії 30.08.2013 


\section{АВТОРАМ ПРО ЖУРНАЛ}

Для публікації в «Фізіологічному журналі» приймаються оригінальні статті 3 основних розділів фізіології, а також огляди (на замовлення редакції), які відображають найбільш актуальні іiі проблеми, статті 3 історії вітчизняної та світової фізіологічної науки, які висвітлюють генезис і еволюцію ідей, виникнення та розвиток наукових шкіл, творчі портрети вчених, забуті імена науки, дискусійні статті, рецензії на статті та нові видання, наукову хроніку, оформлені відповідно наступних вимог.

\section{Подання та робота $з$ рукописами}

Автор подає рукопис статті у друкованому вигляді (два примірники, разом з оформленим ліцензійним договором) та в електронній формі.

Друковані примірники рукопису можна надіслати звичайною поштою (простим листом) або особисто принести до редакції.

В електронному форматі рукопис можна подати на компакт-диску (у разі відправлення поштою вкласти його до конверта разом 3 друкованими примірниками), на USB-накопичувачі (тільки під час подання особисто!) або електронною поштою як прикріплені файли.

Компакт-диск і USB-накопичувач мають бути попередньо перевірені надійною антивірусною програмою і містити тільки файли рукопису.

Правила оформлення рукопису подано нижче.

\section{Поштова адреса редакції:}

Редакція “Фізіологічний журнал”, Інститут фізіології ім. О.О. Богомольця НАН України, вул. Богомольця, 4, Київ 24, 01024

Телефон для довідок: 256-25-27; 253-07-45

Адреса електронної пошти:

fiziol_z@biph.kiev.ua

Матеріали статті - текст, резюме, список літератури, підписи до рисунків і таблиці - оформлюються одним файлом. Окремим файлом оформлюється кожний рисунок. Усі сторінки рукопису нумеруються. Крім того, в тексті слід указати де саме треба розмістити рисунки/таблиці. Формат файлів для тексту і таблиць - документ MS Word (doc, docx або $\mathrm{rtf})$, для рисунків та іншого ілюстративного матеріалу - tif, bmp, wmf, gif, jpg, eps або pdf. На окремій сторінці варто навести відомості про авторів: прізвище, ім'я, по батькові, поштову і обов'язково електронну адреси, номери службових й домашніх телефонів із кодом міста, номери мобільних телефонів. Якщо авторів кілька і вони працюють у різних установах, слід позначити арабськими цифрами (індексами) у кінці прізвищ авторів відповідність установам, в яких вони працюють.

Датою отримання рукопису вважається дата надходження його до редакції. У разі одержання статті, оформленої з порушенням цих правил, редакція залишає за собою право статтю не приймати, не рецензувати і не повертати авторам, про що їх повідомляє.

Поданий до журналу рукопис обов'язково рецензується провідними спеціалістами у відповідній галузі. У разі необхідності рукопис направляється авторам на доопрацювання. Після доопрацювання рукопису згідно із зауваженнями рецензентів автор надсилає його до редакції разом із відповідями рецензентові протягом одного місяця. Рукопис, що отримав недостатньо високу оцінку рецензентів, відхиляється як невідповідний профілю та вимогам до рівня публікацій журналу.

Для контрольного ознайомлення 3 відредагованою статтею редакція надсилає авторові електронною поштою верстку, яку треба терміново вичитати і не пізніше трьох наступних днів електронною поштою повідомити редакцію про виявлені помилки (зазначивши сторінку, колонку, абзац, рядок, де слід зробити виправлення) або про їх відсутність. На цій стадії роботи з рукописом не дозволяється заміна тексту, рисунків, таблиць. Якщо відповідь від авторів вчасно не надійшла, редакція залишає за собою право затримати публікацію статті.

\section{Загальні вимоги до рукописів}

Обсяг експериментальної роботи зі списком цитованої літератури, таблицями та рисунками 3 підписами, що пояснюють одержані результати (все на окремих сторінках), має не перевищувати 20 сторінок (40 тис. знаків), огляду - 30 сторінок (60 тис. знаків), надрукованих на принтері.

Рисунки, фотографії, схеми тощо можуть бути чорно-білими або кольоровими. 
Рукопис статті має бути підписаний кожним автором.

Наприкінці статті після списку літератури додаються назва статті, ініціали та прізвища авторів, офіційні назви установ, де виконано роботу, електронна адреса. Резюме і ключові слова російською та англійською мовами відповідно до оригінального українського тексту. Якщо статтю написано російською чи англійською мовою, ця інформація подається відповідно українською та англійською чи українською та російською мовами.

\section{Окремі вимоги до оформлення рукопису}

\section{Текст}

Шрифт - Times New Roman; кегль 14 (таблиці - кегль 10); інтервал між рядками - 1,5. Таблииі та ілюстративний матеріал

Усім колонкам у таблицях слід дати назву i вони мають бути заповнені відповідними даними (якщо дослід не проводили, треба ставити "_.", а якщо показники не встановлено - "0").

На фотовідбитках зазначається їх верх.

На полях рукопису слід помітити місця розташування рисунків і таблиць.

Структура рукопису

УДК

Назва статті

Ініціали та прізвища автора (-ів)

Назва установи, де було виконано роботу

Електронна адреса для листування

Резюме і ключові слова

Вступ

Методика

Результати та їх обговорення

Висновки

Подяка

Список літератури

\section{Резюме і ключові слова}

В резюме стисло висвітлюються основні результати дослідження.

Резюме має включати основні розділи:

- актуальність

- постановку проблеми,

- шляхи вирішення поставленої задачі,

- результати,

- висновки.

Вступ (без назви)

На початку статті стисло викладається історія питання з посиланням на джерела літератури та обгрунтування мети дослідження.

\section{Методика}

Розділ “Методика" має бути поданим так, щоб за наведеним описом методів і реактивів, умов проведення дослідів можна було би відтворити експерименти. На загальновідомі методи досить дати посилання на публікації. Слід навести назви фірм та зазначити країни-виробники реактивів і матеріалів, які було використано в дослідах; вид і кількість дослідних тварин і обов'язково застосовані методи знеболювання та евтаназії.

Цифрові результати слід заокруглювати згідно з усталеними правилами, враховуючи середню похибку досліду. Вірогідність відмінностей показників слід обгрунтувати статистичним аналізом, посилаючись на конкретні методи. Не можна наводити одні й ті самі результати в таблицях і на рисунках. Слід також вказати за допомогою якої програми було зроблено статистичний аналіз одержаних результатів, як подано результати, який довірчий інтервал або розподіл величин.

Усі позначення і найменування фізичних і хімічних одиниць вимірювання наводять у системі СI.

Скорочення слів (абревіатури), крім загальновідомих, у таблицях і в підписах до рисунків наводити не варто (за деяким винятком, в цьому разі обов'язковим розшифруванням їх у примітках), Не слід також, окрім загальноприйнятих скорочень, наводити у статті довільно скорочені короткі слова (наприклад, так як каталаза тощо).

\section{Результати та їх обговорення}

У цьому розділі слід уникати прямого повторення результатів таблиць. Обговорення результатів потрібно обмежити розглядом лише найважливіших встановлених фактів 3 урахуванням попередніх даних щодо питання, що вивчалося. Іншими словами, більша частина обговорення має бути присвячена інтерпретації результатів.

\section{Висновки (без назви)}

Список літератури. Для зручної та швидкої обробки вашої роботи в реферативних базах пропонуємо подавати список літератури в форматі Vancouver Style, опис якого можна знайти за адресою: http://www.nlm.nih.gov/ bsd/uniform_requirements.html 


\section{ЛІЦЕНЗІЙНИЙ ДОГОВІР НА ВИКОРИСТАННЯ ТВОРУ}

м. Київ

«" 201_p.

Інститут фізіології ім. О.О. Богомольця НАН України як засновник та видавень журналу «Фізіологічний журнал (далі - «Виконавець») в особі директора академіка НАН України О.О.Кришталя, що діє на підставі Статуту, з одного боку, та Автор(и)

(Прізвище, імя , по-батькові автора(ів))

(далі - «Автор», з іншого боку, разом іменовані «Сторони», підписали цей Договір (майнове виключне право) про наступне:

1. Автор(и) безоплатно надають Видавцю виключну ліцензію на друк та використання письмового твору (далі «Стаття»)

в тому числі права дозволяти або забороняти використання Статті або ï частини третіми особами у будь-якій формі і будь-якими способами.

2. 3 моменту підписання цього договору (за умови прийняття Статті «до друку») Видавцеві належить право оприлюднити, редагувати, адаптувати і модифікувати, перекладати на іншу мову, видавати, а також розповсюджувати Статтю необмеженим накладом у будьякому вигляді та форматі на різних носіях інформації і будь-якими способами.

3. Ліцензія на викориистання Статті надається Видавцю на весь термін дії авторського права на зазначену вище Статтю і має силу на території всіх країн світу.

4. Виконавець набуває право субліцензувати права, отримані за цим Договором, іншим установам та особам.

5. Всі копії Статті як паперові, так і електронні (включаючи CD, DVD та інші електронні засоби масової інформації, Інтернет і інші мережі передачі даних і бази даних), мають містити інформацію про авторські права Видавця і повне бібліографічне посилання на Статтю.

6. У разі, якщо рукопис Статті не буде прийнято до друку протягом 18 місяців (про що Автору буде повідомлено в письмовій формі) або відкликано Автором до прийняття Статті «до друку», цей Договір втрачає силу і анулюється, а авторські права повертаються Автору.

7. Видавець підтверджує збереження за Автором наступних прав:

- авторське немайнове право згідно з чинним законодавством України;

- патентні права, права на торгівельні марки і права на будь-які процеси, речовини, матеріали та методи, описані у Статті;

- права на виготовлення різних копій, зокрема електронних, винятково для власного використання або колегами Автора за умови, що копії Статті не будуть використані ним для продажу та для систематичного розповсюдження;

- права наступного використання Автором всієї Статті або будь-яких її частин в оглядах, дисертаційних роботах, книгах, лекціях. 
8. Автор гарантує, що Стаття не була раніше надрукована і не буде надрукована будь-де до іiї публікації Видавцем, а також те, що авторські права на ії публікацію не передавались іншим видавництвам.

9. Автор гарантує, що Стаття є оригінальною роботою Автора і не є копією будь-якої іншої роботи. Автор гарантує, що ним одержано всі необхідні дозволи на використання матеріалів у своїй Статті, що охороняються авторським правом.

10. Автор гарантує, що використання Видавцем авторських прав, набутих внаслідок цього Договору, не спричинить порушення авторських прав будь-яких осіб або організацій, а також не призведе до розголошення секретних або конфіденційних відомостей.

11. Видавець має право встановлювати правила (умови) прийому та опублікування матеріалів Журналу. Редколегії журналу належить виключне право відбору та/або відхилення матеріалів, що надсилаються до редакції з метою їх опублікування. Рукопис, що спрямовується Автором (Співавторами) до редакції, поверненню не підлягає. Листування щодо відхилення статті редколегією Жураналу не підтримує. Видавець не несе відповідальність за неправдиву інформацію надану авторами.

12. Договір є чинним з дати його підписання Сторонами та укладається на термін чинності авторського права на Статтю. Відносини, що неврегульовані цим Договором, регулюються чинним законодавством України.

13. Автори виключно для цілей виконання даного договору надають для внутрішнього користування Видавця згоду на обробку та використання зазначених у цьому Договорі персональних даних згідно з Законом України “Про захист персональних даних". Усі положення цього Закону роз'яснені Видавцем Автору.

14. Всі доповнення, додатки, акти складаються Сторонами в письмовому вигляді i підписуються вповноваженими представниками Сторін.

15. Цей Договір складено у двох примірниках українською мовою, тексти яких автентичні, по одному для кожної зі Сторін.

\section{Підписи Сторін:}

\section{Автор}

П.І.Б.

Адреса:

Тел. _ E-mail:

Підпис

\section{Видавець}

Інститут фізіології ім. О.О. Богомольця НАН України

вул. Богомольця, 4, 01024, Київ, Україна

Тел. (044) 256-25-27

E-mail: fiziol_z@biph.kiev.ua

Директор Інституту, академік НАН України

О.О. Кришталь

Підпис 


\section{CONTENTS}

V.A. Yavorsky, E.A. Lukyanetz. Using serial tachograms to measure the evoked impulse activity of isolated hippocampal neurons

O.V. Kalinichenko, T.M. Myshunina, M.D. Tron'ko. Changes in active cysteine cathepsins in lysosomes from tissues thyroid papillary carcinomas with various biological characteristics

N.D. Nosenko, A.A. Lymareva. Peculiarities of sexual behavior of female rats with hyperandrogenia in pubertal and postpubertal periods

I.V. Golovchenko, N.I. Hayday. Cerebral hemodynamics in children of 8-12 years old with alterations of the motor activity of central origin

V.A. Golovko, E.A. Lebedeva. The contribution of lidocaine- and ttx- sensitive current in generating of upstroke action potential in the cells of sinuauricular region of mice

A.G. Morenko, O.S. Pavlovuch, I.Ya. Kotsan. Features of cortical activation processes in men during auditorimotor activity of different complexity

O.G. Rodinsky, O.G. Zinovieva, O.V. Mozgunov, O.S. Trushenko. The activity of the interneuron pools of the spinal cord in experimental diabetes mellitus

Zh.A.Kruchenko, N.A.Pilkewich. Influence of intranasal administration of dopamine on realization of cognitive processes and locomotor activity of rats during stress

B.O. Manko, V.V.Manko. Influence of adenosine diphosphate on respiration of rat pancreatic acinar cells mitochondria in situ

O.A.Khodakovskiy. Characteristics of antiischemic and mnemotropic properties of ademol under model of acute disorder of encephalic circulation

Ya. V. Lesyk, R. S. Fedoruk, O. P. Dolaychuk. Immunobiological blood parameters in rabbits after addition to the diet suspensions of chlorella, sodium sulfate, citrate and chromium chloride

REWIEWS

S.A. Talanov, T.I. Lyashenko, I.I. Patalakh. The role of nadph-oxidase in paracrine and autocrine regulation of platelet functional activity

\section{JUBILEE DATES}

I.A. Vladimirova, I.B. Filippov. Contribution of Academician MF Coats in the understanding of mechanisms of synaptic transmission in smooth muscles 